\title{
What a Mask Reveals-- Assessing Chinese and American Societal Differences
}

\author{
Shangkai Su \\ Loudoun School for Advanced Studies, 20577 Ashburn Rd, Ashburn, VA 20147 \\ *Corresponding author.Email: justinguo@xyzrgroup.com
}

\begin{abstract}
The usage of personal protection equipment (PPE) such as face masks diversify immensely in the US and China during the COVID-19 pandemic. To fully address this issue, this paper conducts a multi-aspect research on US and China society. This research aims to compare the two cultures and identify the underlying problems paramount within the two societies, which caused the different approach to using and regulating PPEs. Comparisons were conducted on four different domains: public culture, system, policy, and global supply chains. Findings from these research show that (a) China holds a strong collectivist value shaped by Confucianism traditions, and the US holds an individualistic value inspired especially by Lockean liberalism; (b) The top-down model and federalism model provides different levels of central power; (c) The pandemic is politicized in both countries: US policies show a heavy distrust in science, and China seeks to gain foreign-policy interests through mask diplomacy; (d) Trade barriers, created due to cultural differences and political significance, injure the supply chains of medical supplies. The author hopes that this research will offer insights to researchers and policy-makers interested in COCID-19 and cross-cultural comparisons.
\end{abstract}

Keywords: COVID-19, Cross-cultural comparison, US-China relations, Global trade

\section{INTRODUCTION}

Face masks, something that has been proven to be effective at slowing the spread of the novel coronavirus, experienced different fates in China and the United States: more people wear masks in China than in the US. According to an international survey conducted by YouGov in March 2020, when China was in the midst of its epidemic, 85 percent of Chinese wore masks outside their homes.[1] A more detailed survey conducted in Henan province, China, revealed that as high as $96.2 \%$ of people in the province "wore masks outside" .[2] On the other hand, according to a Gallup Panel survey conducted from June 29-July 5 (after the pandemic had already been raging for months), only 44 percent of adults in America “always" and 28 percent "very often" wear masks outside their homes.[3] This sharp contrast is influenced by four factors: public opinion, systems structure, political influences, and trade policies, all of which are completely different in the two countries. These factors will be explained by the author' s research through four spheres: culture, system, politics, and economy. This paper is intended to provide the reader with a deeper insight into these four spheres of the two different nations.

In the first section, the author will dissect the first factor, public opinion, by digging into the fundamental beliefs and cultures of the two countries; different systems will be addressed in the second section by comparing the political philosophy on which the systems are built; the third section will focus on contemporary politics in order to explain different policies concerning masks; the last section will discuss the trade of masks, and will elaborate on the incentives and problems of the business on both the national and personal levels.

\section{CULTURE \& PUBLIC RESPONSE}

In this section, I will address the difference in public responses for mask-wearing, and explore the roots for these responses and behaviors by analyzing the culture of the two countries.

In China, many people already started to wear masks even before the government announced requirements and regulations. After understanding the severity of the epidemic, most Chinese citizens felt responsible about the necessity of wearing masks. Complaints against 
mask-wearing were few among the general public, protests were unheard of. The same attitude can not be observed in America, where states trying to push facecovering requirements often faced strong opposition from its citizens and communities; where protests against mask-wearing and stay-at-home orders were almost everywhere; many officials, including former President Trump himself for several months, refused to wear masks. This disparity in the public responses of the two countries can be explained by their basic values and culture. (The system and politics also have their implications for the public responses, which will be discussed in the later sections).

Let' s start by comparing the core values of the two societies: China' $\mathrm{s}$ collectivism and America' $\mathrm{s}$ individualism. The Dutch social psychologist Geert Hofstede has analyzed research on Cultural Dimensions [4] by comparing different national values on six dimensions. The comparison between China and the United States and the world average are shown in the figures below.

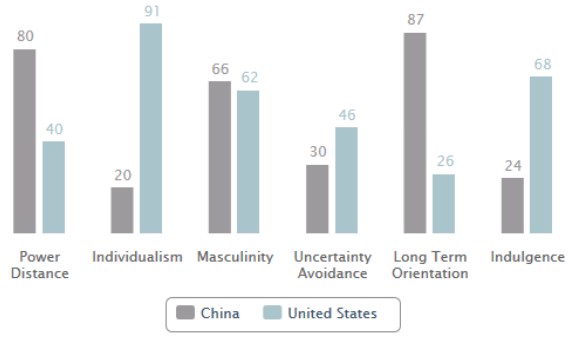

Figure 1. The comparison between China and the United States and the world average

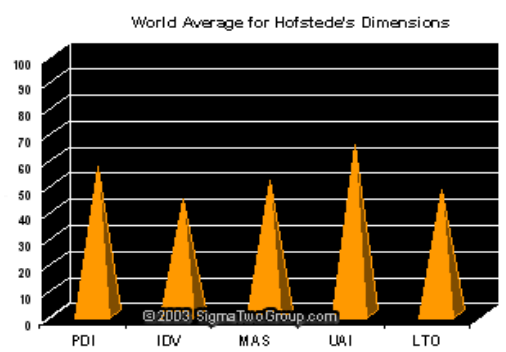

Figure 2. World Average for Hofstede's Dimensions

In the "Individualism" dimension, the United States ranks the highest in the world, with a score of 91; while China only scored a 20 . Both scores are significantly above or below the world average level, ranking 43 (shown in figure 2) -- they are almost two ends of the column. Thus, it is reasonable to infer that American society has a strong individualism tendency, and Chinese society has a strong collectivist tendency.

Individualism indicates that there is a greater importance placed on attaining personal goals. Collectivism indicates that there is a greater importance placed on the goals and well-being of the group.[5] I will explain the roots of these value tendencies below and expand on these notions in terms of public opinions.
Going into the culture of the two countries is helpful to explain this value tendency. Collectivism in China goes back to Confucianist and Taoist philosophy. The measure of collectivism is the tie between the individual and the group. In Chinese culture, this tie is demonstrated in three relationships: between man and nature, man and the state, and man and family. "Tian Ren He Yi (Unity of Human and Heaven) ", a core concept in Taoism, is the central pillar of the Chinese worldview. It describes the macroscopic relationship between man and nature. "Heaven" is not only the universe but also the "Tao", representing the "nature" form. Humans cannot be separated from the "Heaven" and "Earth", so they have to be in harmony with the world, and accept its natural laws. This belief praises the unity between man and nature, and denies individualistic practices. The relationship between man and nation, similar to the term "society", is also discussed in Confucianism. Social propriety and virtue is demanded from both the ruler and the people, as described, "A prince should employ his minister according to the rules of propriety; ministers should serve their prince with faithfulness" (The Analects 3:20).[6] The unity between man and the state can be reflected in the word for state in Chinese, “国家 guojia”, which combines the character for country, “国 guo " and the character for family, “家jia”. This reflects the belief that the state is just a family in a larger perspective, and each person ties closely with the state as a family member. Therefore, the family unit is the epitome for the state, and the obligations and rules in the family reflect the society. "Filial piety", "benevolence", and "rites" are the most important virtues in Confucianism, and being filial is the first step to build these virtues, as described in the Analects: "Filial piety and fraternal submission!- are they not the root of all benevolent actions?"(The Analects 1:2). As Confucius said, Filial piety is not only to "support", but also is about "reverence" (The Analects 2:7). This reverence holds the tie between youngsters and elders, forming a strong family bond; and the obligation to "support" requires the young to be dedicated not only to their own lives, but also to their family members.

The individualist value of America is the result of its liberalism, rooted deeply in American culture. The land of America was transformed by immigrants who felt their rights to liberty restricted by the rigid social structure of Europe, and the nation - the United States- was founded by men who felt their rights to property were taken away by the British government. This history forms "the American creed", as Thomas Jefferson described. In "The Liberal Tradition in America" (1955), Louis Hartz argues that "the master assumption of American political thought" is "the reality of atomistic social freedom. It is instinctive in the American mind." (Hartz, p. 62) According to Hartz, the United States has always been under the reign of "Lokian [Lockean] ideology", a set of ideas from philosopher John Locke that heavily 
influenced the founding fathers. Hartz claims the Lokean ideology is "a colossal, absolutist liberalism" which defines American culture.[7] This rooted liberalism inspires the actions of an individualist approach. In his work, Alexis de Tocqueville identified "individualism" as one of the foundations of America's democracy and culture.[8] According to Tocqueville, Americans are "born free" without hereditary distinctions, thus having the opportunity to rise in society by pursuing their own interests, weaving the American Dream. In other words, freedom in American society bornes the pursuit for individual success, creating a social model of an individualistic nature.

Major scientific opinions suggest that the use of masks functions less for individual protection but more for slowing community spread. Anne Rimon, an epidemiologist at UCLA, explained it this way: Masks "are not to protect you from someone else, they're to protect someone else from you".[9] While both societies understood this use of masks, they showed very different responses. Chinese people, having a group-oriented mindset, naturally tend to feel a responsibility for protecting others. The idea of social and family obligation in Confucianism also provides Chinese people a moral compass for wearing masks en masse. For instance, the phrase mentioned by many people, "Every single man is responsible for the rise and fall of his nation” (国家兴亡, 匹夫有责), reflects Chinese people’s responses to the pandemic-- under the greater crisis of the nation, everybody dedicated to the common good of the society. While Chinese people use that phrase to inspire dedication to the country, Americans use the phrase "I have the right to..." to justify their individualist actions. In America, the main reason against wearing-masks and stay-at-home goes that these requirements are impeding people's liberty, the central concept in Lockean and Jeffersonian ideologies. The enforcement of maskwearing is perceived as an abuse of governmental power, which should be limited. To these Americans, refusing to wear masks is a small protest against governmental control and a statement to guard their individual rights and freedom. In conclusion, thanks to China's collectivist values, Chinese people complied with mask-wearing orders, thus controlling the pandemic spread relatively quickly; while many Americans rejected the use of face masks due to their individualistic view, thus causing more infections.

However, is America completely hopeless for its notat-all collectivist beliefs? The answer is no. The idea of giving up individual rights to the collective is not completely unfounded in America's basic beliefs. The "Lockean ideology" not only includes natural rights, but also the social contract theory. Social contract theories from Locke and other philosophers such as Hobbes and Rousseau describe a form of agreement voluntarily established between individuals and the government in order to maintain the sovereignty and order of the society.
In agreement for relinquishing certain rights, individuals would receive protection from physical harm, security for their possessions, and the ability to interact and cooperate with other humans in a stable environment. The scope of governmental authority and obligation is established upon consent. If one is not willing to give up any rights to the authority, no consent will be formed, the society would therefore be in the brutal state of nature, and people's rights will be even more insecure. Even in Washington's Farewell Address, the idea for obeying the government and embracing a collective identity is found, "The very idea of the power and right of the People to establish Government presupposes the duty of every individual to obey the established Government." In exchange for some little amount of liberty from each individual, the government will ensure the collective optimum and thus greater liberty for the society. In the modern United States, it's not hard to hear the phrase "I have the right to...", but one can rarely hear people saying "I have the responsibility to...". While fighting for personal "liberty", people should at the same time shoulder more societal "responsibility". As President Kennedy said, at Amherst College in 1963, "Privilege is here, and with privilege goes responsibility.”[10]

\section{SYSTEM STRUCTURES}

In this section, I will describe and compare the political systems of China and the US, and then evaluate the benefits and downsides of each system for maskwearing and countering covid-19.

The forming of different systems is the result of the distinctive culture and social norms in each society. Believing in benevolence in governing, and being ruled by the "Son of Heaven" for over two thousand years, Chinese society accommodates a strong and reliable central authority; distrusting strong government and fearing empires, America's "liberal tradition" prefers a regulated authority that does not interfere with people's freedom -- these cultural traditions shape the societies we live in today. No system shall be universally defined as good or bad because even the "best" systems have flaws, and even the most unpopular system has its benefits. In the COVID-19 pandemic, China and America's systems each showed its own benefits and downsides.

The political systems are different: China operates under a single-party system and the United States operates under a two-party system. The two-party system has existed since the beginnings of the Republic, first in the opposition between the Federalists and the AntiFederalists and now in the competition between the Republicans and the Democrats. While the two-party system represents and reconciles conflicting interests of the people, it inevitably encourages political conflicts and strife. As Edmund Burke put it in 1769, "Party divisions, whether on the whole operating for good or evil, are things inseparable from free government." -- it is a price 
paid for political freedom. Because of the relative equal strength of the two parties, competitiveness and rivalry in politics are high. Many efforts of one party aim to suppress the other party rather than for the national interest, and due to the frequent shift of powers between the two parties, a stable and coherent national agenda is hard to produce. During the Covid-19 outbreak, the Republican party and the Democratic party had divergent views on mask-wearing-- Democrats are shown much more likely to wear masks than Republicans according to surveys, with $61 \%$ of Democrats responding that they "always" wear masks while only $24 \%$ of Republicans "always" wear masks (Brenan). In fact, party identification is the biggest factor that affects the choices of mask-wearing. For both sides, masks have become a political symbol. For the Republicans, not wearing masks symbolizes a disregard for experts, a wish to bring back the economy, and a statement of loyalty to party leadership. For the Democrats, wearing masks reflect a trust in science, a respect for health guidelines, and an implicit message of going against the Republican approaches. The decision of whether to wear masks has therefore become less of a choice about right or wrong, but more of a choice to take side in a partisan competition.

China is ruled by a single party-- the Chinese Communist Party, or CCP. Unlike America's parties, which have more flexible party structures, the CCP is an extensive party with a clear "top-down" hierarchical structure. In this way, lower offices function as pure executives and would not oppose decisions from the top. This unifies the voice within the party and, since it is the only party in power, within the full governmental body. Unlike America's national elections, Chinese elections occur within the party, therefore higher governmental positions are reserved for party members. Even when the shift of leadership occurs, the government still retains a relatively consistent agenda. While the single-party structure lacks representation and political freedom, it is more stable and consistent than a two-party or multiparty structure. The stable domination of one party is the reason why China can effectively generate long-term planning and programs. In addition, the blurred line between "government" and "the party" actually aligned the national interest with party interest. After all, the Party is the only organization to be blamed when things go wrong, therefore it is according to its interest to secure the safety of the people. During the pandemic, the Communist Party has shown great determination in controlling the pandemic for both the party's interest and the national interest. All decisions were also made quickly, because of the unified voice within the governmental body.

The role of the federal government in America has been long debated, causing the first party split: Federalist and Republicans. Federalists such as Alexander Hamilton and John Adams argued for a strong federal government to unite the states; while Republicans such as Thomas Jefferson argued for a weak federal authority. Jefferson insisted till the end that the true 'spirit of 76' was incompatible with federal authority over domestic policy. A compromise was made that a federal system based on the constitution shall be established, where state governments enjoy extensive authority within their borders, while powers to regulate national and international issues are reserved to the federal government. While the system is delicately designed, the federal government did not utilize its full power in COVID-19. The White House did not release any national guidelines, and the Congress did not pass any substantial policies in regard to the virus, other than a stimulus package. Without much help from the federal level, states, counties and residents were left to make their own choices, either in line with or against public health advice. It is said that the United States doesn't have two parties but a hundred, two for each state. The phrase somewhat captures the current situation. Whether not to wear masks is related to demographics and party alignments, therefore a united and consistent tone has not appeared.

China is organized along unitary rather than federal principles. Both the government and the Chinese Communist Party, moreover, operate "from the top down", having a direct commanding structure between central, provincial, and local government. To run the country, the government and the CCP have established roughly parallel national bureaucracies extending from Beijing down to local levels. There are 24 levels of government and in total 10 million government officials in China. In this complex hierarchical system, information transmission from top down is effective. However, any transmission from below to the top would be hard, since information can be stuck at any level during the report. In January, 2020, news of the discovery of the Novel Coronavirus was hidden by Wuhan's local and provincial bureaucracy for two weeks before it was heard by the central government, thereby delaying China's identification of the virus. This delay cost China and the world many lives. A similar situation happened during China's Great Famine in 1960, where lower officials lied about the number of crops when reporting to the top. However, this system can also have immense power to put orders into action. Since lower offices don't oppose higher ones, and operational roles are well assigned, decisions from the top can be implemented in daily life very efficiently. As soon as China's central government noticed the new virus, they immediately decided to lock down Wuhan, in the meantime doing other helpful actions with unbelievable speed. The results were victorious: within 10 days, China was able to build two hospitals and test 14 million people in Wuhan; within two months, the pandemic was controlled. In fact, China is still making every effort to this day, almost excessively, to control any further spread. Recently, 
when I traveled from Shanghai to a city nearby, I was stopped and questioned because during my travel to Beijing a month before, my train passed through Qingdao en route. At that time there were six infected people at Qingdao. I had not physically been to Qingdao, nor did coronavirus cases exist there the month before. Just because I had the tiniest connection to the place with six infectants, I was detained for an hour. This excessiveness certainly creates a lot of inconvenience on the personal level, but overall it is effective in tracking and controlling the pandemic spread. This would not happen in the United States, due to the limitations of governmental power. There is not even a basic travel ban enforced in the United States. This difference of executional ability between the central governments of the two countries was one of the deciding factors that influenced the outcome of fighting the virus.

In the specific circumstances of COVID-19, China's system showed more benefits than downsides, and the United States' system allowed difficulties and problems. What should the United States do with its system to help stop the virus? Within the framework of the American governmental system, properly expanding the federal power is necessary to solve national crises. Since the state government neither has the legitimate authority nor the power to regulate national issues, federal intervention may be essential in the face of national crises. We have seen that federal power expansion many times in history. Although the Constitution has laid out a balance of powers between the state and federal government, in reality the federal power has expanded a lot since the Civil War, especially to provide aid in times of crisis. Almost all national crises are solved by the stepping in of federal power, and under the greater common threat, the American people have oftentimes been in favor of that intervention . During the Great Depression, Americans welcomed the expansion of federal power that came with Roosevelt's New Deal; during World War II, Americans largely accepted the rationing of food and the shifts of the economy sector that are all in service of the war; after the attack of 9-11, many Americans supported the creation of the Homeland Security Act and other new security rules that infringed on personal liberty; even during the 1918 pandemic, when there was very little scientific knowledge about viruses, most people supported wearing masks. In all these cases, a sense of patriotism and national unity transcended the liberal tradition that resents strong government. By recognizing that the enemy is the virus rather than the other party, and reestablishing the trust to government under patriotism, the federal government can perhaps step in and accomplish its responsibility to save the nation.

\section{POLITICAL INFLUENCES}

In this and the next section, I will shift my focus from the bases of the societies to the contemporary events during the COVID-19 outbreak, and discuss their contexts. In this section, I will focus on current politics, which are also defined by the scopes and structures of the systems.

In the United States, many health issues concerning the COVID-19 pandemic have taken on a heavy political tone. The Trump administration employed its political agenda in choosing the nation's official coronavirus task force, selecting members based on ideological tendencies rather than scientific merits. Political loyalty is demanded even for scientists. Dr. Fauci said in an interview, that scientists "needed to have a medical message that was essentially consistent with what they (government officials) were saying."[11] According to him, the only medical person who saw the president on a regular basis was Scott Atlas, one of the few health professionals who agrees with Trump on medical issues such as the efficacy of masks. Scientists who openly oppose government opinions have been either silenced or dismissed. Nancy Messonnier, the CDC director who whistleblowed the consequences of COVID-19, was silenced from all public briefings[12]. Dr. Rick Bright, who had been deputy assistant secretary of health and human services (HHS) and director of the Biomedical Advanced Research and Development Authority (BARDA), was removed from office for criticizing CDC and the Trump administration.[13] These incidents provide examples for the government's attempts to control scientists' speeches to conform with its own messages. Science was therefore, to some degree, compromised by political loyalty.

Many more political moves were made under the cover of creating safety programs. The China ban, a policy that denies entry to the US border for any foreigners that have been to China for the last 14 days, is a typical example. Although the policy effectively blocked foreigners from China, Americans traveling back from China were not restricted. Even after this ban, thousands of Americans returned to their country without being quarantined, thus further spreading the virus. This seemingly scientific policy tells the same old story of "build a wall" under Trump's political agenda.

The tendency to view the pandemic through partisan lenses was also strong. As the presidential election approached, the competition between the two parties intensified. President Trump, not willing to be seen by voters as a coward, decided to maintain his methods until the end; and Democratic candidate Joseph Biden, eager to present himself as a new hope, heavily criticized Trump's actions and insisted to take a different approach. As mentioned earlier, the decisions over health issues have become less of a choice about right or wrong, but more of a choice to take side in a partisan competition. These problems tie back to the two-party system and the rapid shifts of administrations, which creates conflict, reduces coherency, and often causes partisan politics to surpass the common ground of national interest. 
There is a growing distrust of science among segments of the American people, highlighted by the climate crisis and anti-vaccine movement. Supported by a tradition that favors individual liberty and free will, some people become skeptical of scientists, whose influence seemingly grew too strong in affecting everyday decisions. Americans with doubts about science were, unsurprisingly, less likely to trust public health experts for information on COVID-19. Among those trusting science, $78 \%$ reported trusting medical experts and $73 \%$ trusted U.S. health agencies like the National Institutes of Health for accurate information about COVID-19. Among science doubters, only $36 \%$ trusted medical experts and 32\% trusted national health agencies for accurate COVID-19 information. In an infectious disease context, the subset of the public not convinced by scientific recommendations puts everyone at risk.[14]

The tendency to distrust science was further encouraged under the lead of an administration that constantly denied science, which further practised a disregard for sciences during the COVID-19 outbreak. Many policies without much scientific support were suggested and promoted. For example, the White House insisted to accelerate the vaccine development despite the warning of scientists; hydroxychloroquine and azithromycin, drugs without much scientific evidence, were promoted by the President; the President even used the warning that "Democrats will listen to the scientists" to sway people not to vote for Joseph Biden in one public convention.

Throughout the pandemic, President Trump retained an attitude of disregard towards the virus. He refused to wear a mask for several months, encouraged states not to lockdown, even suggesting the pandemic was a Democrat hoax to beat him. It's not that the President believes the virus isn't serious, in fact, he understood well the severity of the virus. In a call with journalist Bob Woodward, Trump said he was aware that the virus spreads by air and is more deadly than the flu. Despite having a clear understanding himself, he did not express the same knowledge to the public. Trump downplayed the severity of the pandemic in almost every public briefing, admitting he "[didn't] want to create panic"[15]. Why would the President deliberately choose to misinform the public with messages which not even himself agrees with? A likely explanation is that it's for his own political purposes. The strength of the economy has been one of Trump's biggest accomplishments, and maintaining this accomplishment was seen as essential to his reelection. When weighing people's lives and the economy, he decided that perhaps, the economy is more important for his political success.

From the outside, China's politics isn't as intricate as American politics, but it's still worth reviewing how the
CCP pushed its political and strategic goals in the pandemic.

China is trying to promote its reputation as a reliable international leader, by exporting masks and sending aid packets to countries around the world. China's choice to send masks has shown a strong political tendency For example, countries with sister linkages to Chinese provinces received substantially more donations of medical equipment, whereas countries that recognize Taiwan do not receive any donations from China at all.[16] Using the narrative of humanitarian aid, China is strengthening its political ties with its allies, promoting its image as a ready international leader, and seeking to gain access to the infrastructure market of these nations. China is also promoting its morals domestically. As China aided countries that were hit, the Chinese state media were quick to portray China's own donations as acts of benevolence (Popescu, 2020).[17] Despite the skepticism from Western countries over this strategic aid, most countries that received the aid publicly expressed gratitude for China.

In addition to establishing political influence abroad, the Chinese government was also promoting its patriotic propaganda at home. Moral cultivation, a type of propaganda that intends to give meaning to big events or crises, has been brought again to Chinese after the covid19 epidemic. The "great anti-epidemic spirit" is the theme of this campaign. Mentioned by General Secretary Xi Jinping on September the eighth, the anti-epidemic spirit was summarized into the line: "Life comes first/the nation united /undaunted by perils /respecting science /shared fate of all."[ Note: Translation by the author. Original:

“生命至上 举国同心 舍生忘死 尊重科学 命运与共。” The anti-epidemic spirit has been promoted in all kinds of schools across China through textbooks, speeches, and seminars in order to pass down the morale to future communists. This is an example of securitization efforts from the Center to create solidarity and pride out of the success in the fight against coronavirus.

Due to this active propaganda, the fight against coronavirus actually created a sense of nationalism among many Chinese. It can be observed that Chinese people become more united and proud after the pandemic. Combining other countries' failures with China's success, Chinese people's confidence in their own system grew. At the same time, people's perceptions towards the US were worsened. There was a disbelief among everyone of how a country as strong as the United States can't even deal with a pandemic. Seeing the US' failure, many came to the conclusion that the Western democratic system is deeply flawed. To the Chinese government, this is a successful outcome. Not only did the party gained more support from people who were already patriots, but also the system gained recognition 
from people who previously preferred America's democratic model.

The position of leadership is highly valued in virtually all systems. Excellence is always demanded from leadership positions in order to solve crises, and in the US and China's systems, this expectation is often narrowed to one person. A qualified leadership is expected to serve itsgroup, shoulder its responsibility, and reconcile its own interests with the group's. Trump did not take the responsibility to face the crisis and follow public health guidelines, and put his people's lives at risk for his own political interests. Even according to Trump's own standard for success, which he earlier defined as controlling death tolls within 100,000, he has failed to manage the COVID-19 pandemic. Clearly, a leadership crisis is present. In America's system, this kind of leadership crisis can be resolved by an election. As of this writing, Joseph Biden has won the office from Donald Trump. Whether Biden will be a qualified leader in this crisis is unknown, but the fact that the leadership position is changed shows the nation's ability to correct itself. Despite the comparatively short presidential terms in America tending to generate inconsistency and division, it also puts a constant check on the leader's ability, or at least his popularity. The elections, which places the power to decide into the people's hands, serve to break the current situation and find new hopes. In China's system, a leadership crisis would be much harder to resolve. Without a legitimate process to give people the power to choose, when a leader fails to meet people's expectations, nothing less than a revolution can change the circumstances. Especially since the removal of term limitations by General Secretary Xi in 2018, it would be very hard to remove Chinese leaders when they fail during any crises. Though in recent decades leadership issues have not surfaced in China, setting up certain checks against one-man rule, such as dividing the highest power equally among all seven members of the Standing Committee, would be good precautions. However, this is not likely to happen in China given not only the current political state but also the historical traditions that supported powerful emperors for more than twothousand years.

\section{TRADING MASKS}

Throughout February to July, 2020 the United States suffered an extreme shortage of face masks. Therefore, the biggest face mask exporter in the world--China-easily became a major source of import. From March to December 22th 2020, China in total exported 39.4 billion pieces of face masks to the US, according to China's Ministry of Foreign Affairs.[18] The trade with China is essential to acquire the medical gear needed. As the US Congressional Research Service (CRS) observed in a 6 April note, COVID-19 "is drawing attention to the ways in which the US economy depends on manufacturing and supply chains based in China".[19]

The purchase and trade around face masks has a high priority for both the US and China. For the United States, which is hit hard by the pandemic, the importance of face masks for the safety of people is self-evident. Despite face masks being despised by a large section of Americans, they were desperately needed by medical professionals. The stress of restocking face masks was high for both the federal and state governments. China's degree of emphasis for the mask trade can be seen through it letting important diplomats to announce the exports and donations. The mask trade is not only important to gain political support, but would also boost China's economic growth if China can secure overseas mask markets and earn hard currency.

Governments of both nations also weigh this trade heavily in terms of international relations. The existing political and economic tensions between the two nations, highlighted by the trade war, adds another complication to the mask trade. The impact of this trade on diplomatic goals is an important consideration for governmental decisions. For the United States, it is important not to ruin the preceding objectives to the negative balance of trade (or trade deficit). It was certainly inconsistent for the Trump administration to be again overly dependent on Chinese supplies just after a trade war was declared. Accepting and being dependent on face masks from China is therefore controversial. China also has similar concerns over trade relations. China's attempt to maneuver the mask trade through mask diplomacy is a double-edged sword: its people and its ally countries praise the mask export, while democratic countries often criticize this act as a "political manipulation". China has high stakes in mask diplomacy, and it had to act carefully to secure political support amid the contrasting views. Overall, the two countries have not shown willingness to reconcile tensions and fully open up to trade.

The mask trade not only had a diplomatic importance for the government, but also was an attractive market for companies. According to Nielsen Retail, the price of face masks increased by $319 \%$ in the United States between end-January and end-February 2020. Before the pandemic, a box of 100 masks could be bought for less than USD4 in the United States. However, at the end of February, there were reports that single masks were being sold for USD 20. The same phenomenon has been observed with N95 masks, with the price of a box of 20 increasing from USD17 to USD70 (qtd. In OECD). Attracted by this high profit incentive, many new manufacturers jumped in to produce face masks, while wholesalers decided to export to the US/ import from China.

I was gladly involved in this trade myself by importing and distributing PPEs, and most of the themes described in this section were apparent in my own 
experience. From early March to mid-June, I was importing medical and N-95 respirators from China with a friend of mine. We set up a small company to retail these supplies. In addition to importing relatively small amounts and distributing them through the market, I also attempted to contract larger sales with various state governments. The negotiations with the government were pushed but did not succeed, and the profit from retailing was mostly offset by debts. However, I was glad that my supplies were delivered to the people in need, and the experience helped me to learn more about this trade.

I also got to know an array of retailers and factory owners from China. They can be put into two categories. One type of those people are simply profit-driven, which consist the majority. Many of them lost money due to the complexities of the trade, and decided to quit. There are also people who are charity-driven, who exported and distributed the supplies without earning profit. Driven by the traditional belief to "be benevolent to the world", and inspired by the Party's story of helping other nations (mask diplomacy), these people purely intended to donate and help Americans that were hit by the pandemic. These people encountered even bigger failures than those profit-driven ones. So what are the problems around this trade that troubled these people?

The business is crippled mainly by the problems of supply chain policies. The first problem occurs at the transport stage. Complications in logistics and restrictions from customs makes the basic delivery hard. Likely due to the importance of storing medical equipment domestically, China put export license requirements on face masks. Large quantities of products waited in line to be delivered through a limited passage, and the requirement for documents such as sales contracts and export licenses did not speed up the process. In response to the growing dissatisfaction from overseas on the qualities of masks, China enhanced its domestic enforcements and export restrictions.[20] As the regulations and restrictions grow stronger, private businesses struggle to get their products delivered in time. Transactions are therefore delayed and potentially cancelled. I personally had many masks unable to sell due to export restrictions, which had become a big source of debt.

The frequent shift of policies, resulted by the sensitive nature of the trade and governmental strategies, adds to the uncertainty of the market. Revisions on policies over the masks trade were made regularly, often monthly and sometimes weekly. A long business cycle resulting from the limited transport, combined with back-and-forth policies, creates a highly unstable environment. New policies are often inconsistent with the old ones. In a lot of times, when products finally made their way out of the Chinese Customs, a new policy from the US would deny the deal. A lot of these policies are US regulations for imported products. In order to sell to or contract with US customers, FDA or NIOSH approval, for example, are required. Many masks manufactured in China do not meet these strict US standards, which result in more failures in the trade.

In fact, regulations, standards, and paperwork are more complex in America than in China in most markets. This can be explained by the difference in business culture - another major hurdle in the negotiation process. Confucian beliefs always celebrate the human good over laws or rules. Dong Zhongshu (179-104 BC), a celebrated Confucianist philosopher known for his "Interactions Between Man and Heaven" theory, laid out doctrines about a rule by merit. He admitted that praxis, profit and system are logical, but he thought that humans should aspire after righteousness.[21] This belief heavily influences China's business culture. Chinese people tend to rely on interpersonal relationships in business. They value "righteousness" and "faithfulness" in a cooperation sometimes more than regulations and contracts on pen and paper. This trust-based model functions well in China, but on an international stage, Chinese businessmen are sometimes criticized for a lack of recognition for the importance of rules. On the contrary, in American culture, the value of rules and contracts are put in a much higher place. The Roman Republic was a clear example of "rule by law", contrasted to ancient China's rule by benevolence. The Republic set up clear laws, as well as a checks and balances system that inspired the modern day United States. America's business culture therefore has a much higher emphasis on rules and procedures. As described, the regulations for Chinese exported masks are strict. The controversy about quality is that the products that are considered to be unacceptable in the United States are not considered bad in China, where the standards are more lenient. For example, many masks that are disqualified by American standards were sold and used in China. The stricter requirement and higher standards generally ensure American products to have a more controlled quality than that of Chinese products. However, in times like this with an urgent demand for critical supplies, high standards may not have a positive effect.

In an infectious disease context, it is usually more important to insure people can receive the critically needed supplies than to insure the supplies are of top quality. Despite not meeting US standards for filtering efficiency, KN-95[ KN-95 refers to China's face mask standard GB2626-2006, which is equivalent to the US' standard of N95.]masks would still provide a better protection than a surgical or cloth mask [22], and surgical masks from China would still provide much better protection than self-made masks using household materials. However, in light of the domestic shortages in masks, US agencies would rather recommend people to make masks themselves than to accept substandard masks from China. This double standard can reveal the distrust in Chinese products and the underlying political 
incentives. This distrust certainly contributed to other major decisions around mask imports made by top agencies. The FDA issued a series of Emergency Use Authorizations (EUAs) in PPE, mainly for allowing certain face masks produced in China to enter the US market. However, suspicions of Chinese products soon spiked up. After a major test conducted on Chinese products, the FDA in May reduced the number of authorized Chinese companies from 86 to 14.[23] In August, the EUA was finally revoked [24], as FDA decided that the risks of using unrecognized products would outweigh the benefits of getting the public equipped. I cannot make a definite claim on whether the FDA's decision is correct, but what we do know is that in China, where "substandard" masks are widely used among civilians and medical professionals, the pandemic spread was mostly controlled; while in the US, where the same masks are rejected due to quality concerns, infection numbers increase day by day.

American regulations also set up a trade barrier for new mask manufacturers, who have not yet finished the long process of applying for FDA approval. Products with inadequate quality were rejected, even though they might be approved in China. These rejections threw cold water on naive Chinese exporters/donators, who wanted to help Americans out but were unfamiliar with America's requirements and rules. Misinterpretations were spread that Americans are not grateful for China's delivery of essential supplies. There were also stories about Chinese companies being sued by American customers. Many Chinese businessmen therefore deemed Americans as ungrateful and untrustworthy, eliminating more possible cooperation. The irritation by the supply chain policies, the discouragement by regulations' high standard, combined with the disappointment in perceived American attitudes, caused many charity-driven exporters to quit.

Not only is the private sector hobbled by the restrictions and cultural differences, it is also heavily influenced by the political and diplomatic agendas of the governments. As mentioned, the entire trade is under the delicate relation between the two superpowers, and governmental agendas often cloud the free market. For example, though the American market may be profitable, it is not in line with China's mask diplomacy agenda. The Communist Party is more interested in building up its image by sending masks to pro-China countries or potential allies, instead of to its opponent, the United States. Therefore, the trade with the US never received much governmental support, it even saw restrictions. On the American side, setting high regulations for imported products not only has a cultural implication, but more importantly serves to reduce dependency on Chinese supplies. As described, the Trump administration did not want to be having a trade deficit from China again after declaring a trade war. This may also explain why the government would rather suggest people make masks themselves than to accept all the imports from China.

Under the unsuccessful trade of medical supplies, many nations reflected that the global supply chain can be unreliable during a crisis, and any excessive reliance on it could be perilous. White House trade adviser Peter Navarro has remarked that "We are dangerously overdependent on the global supply chain."[25] This is true. Since every nation in the world wants the same product, many countries would nationalize their supplies, thereby putting their trade partners at risk. Yet, no country alone is able to meet the increasing demand of PPEs without trade. The global supply chain played a big role in soothing out severe shortages during the pandemic, and it should remain important. As seen with China and the US, both countries were significantly helped by the importing of foreign supplies when they face severe shortages. However, the governments have shown distrust in the global supply chain and pushed trade barriers either as export restrictions or import controls. Such measures may have negative consequences in pandemic control, and they do not help global health in both a short-run and a long-run. In the short-run, reducing trade puts countries with lower production capacity in immediate perils. In the long-run, establishing trade barriers harm trade relations, and create a protectionist spiral that will lead to a further escalation of export bans.[26] Under this condition, any future access to essential goods will become difficult, as well as costly. Instead of turning inward, the countries should liberalise global trade, which enables cheaper and easier access to essential medical goods. Some things to do would be removing trade barriers, reducing unnecessary quality control, and enabling more logistic routes. In a broader context. countries should walk out from the unilateral consideration and embrace global cooperation and solidarity. International trade should not be regarded as a problem, but as a solution.

\section{CONCLUSION}

I have organized my paper into four distinct sections that focus on different areas. The summarizing remarks and conclusion for each section are below:

1.Chinese people have collectivist values. Influenced by the values of social obligation in Confucianism, people tend to wear masks for protecting others. Americans hold individualist values. The pursuit for personal freedom runs deep in the American culture, causing many to regard masks and liberty-depriving, therefore refusing to wear masks. In the end, I explored the theme of freedom and responsibility.

2. The US's two-party system represents and reconciles different interests, at the same time creates conflict, strife, and partisanship, causing the nation to be divided. China's single-party system unites the national 
agenda. Its top-down structure makes command from the top easy to be enforced while making information from below to top hard to spread. I proposed that central governments are essential in the face of crisis.

3. In the US, the pandemic was heavily politicized; the tendency to distrust science grew strong under the Trump administration. China seeks foreign-policy interests through mask diplomacy (strategic aid to certain countries), at the same time promotes patriotic propaganda at home. In the end I discussed leadership crisis and how the systems can possibly respond to them.

4. The bilateral trade is highly valued by both nations. The market was attractive, but supply chains can be precarious. Restrictions and cultural differences, as well as political and foreign-policy goals, affect the trade and injure the traders. I shared some insight on the importance of the global supply chain and made policies suggestions.

All the different themes inevitably shape our current condition. The systems are forged by the culture; modern politics are within the border of the system; and trade is influenced by both the culture and the political agendas. All these differences influence each other and together shape the year 2020.

As for now in the first quarter of 2021, many subjects discussed in the paper have moved forward. The once soaring mask market has cooled, as domestic production for masks increased in the US. A new leadership rises in the United States, bringing ambitious new agendas, and promises to ameliorate the policies in order to control the pandemic. This can possibly be a turning-point for America's fight against the pandemic. However, the devastating epidemic is not the only question the new administration needs to face. There are still many existing societal issues that have come to surface in 2020 waiting to be resolved. Despite Biden's promising plans, the road is still long for the nation to become fully settled. In China, the nation faces more challenges as the world enters a new stage. There are long-term plans for the CCP to accomplish and new diplomatic strategies to make in face of America's new administration. But as for right now, the Chinese economy is recovering fast, as well as people's confidence. Overall, the devastating effects COVID-19 brought to the US compared to the relatively lesser effects it brought to China can be a big factor to influence the balance of power.

Further applications: This paper intends to analyze "the mask issue" through multiple aspects. I hope that by understanding these aspects, policy-makers today and researchers may find new insights in related topics, such as inter-cultural studies or international relations.

\section{REFERENCES}

[1] “International Coronavirus Survey.” Yougov, p. 2 ,

d25d2506sfb94s.cloudfront.net/cumulus_uploads/d ocument/lmu1i1w91j/YouGov\%20-

\%20International\%20coronavirus\%20March\%202

020.pdf. Accessed 21 August 2020.

[2] Chen, Shen, et al. " Cognition of COVID-19 among Henan residents. ” Chin Ment Health J, 2020, 34(5): 469-474, doi: 10.3969/j.issn.10006729.2020.5.014.

[3] Brenan, Megan. “Americans' Face Mask Usage Varies Greatly by Demographics.” Gallup News, 13July,2020.news.gallup.com/poll/315590/america ns-face-mask-usage-varies-greatly demographics.aspx.

[4] Hofstede, Geert. Dimensionalizing Cultures: The Hofstede Model in Context. Online Readings in Psychology and Culture, 2(1), 2001. doi.org/10.9707/2307-0919.1014.

[5] “What is the Hofstede' s Cultural Dimensions Theory?

CFI corporatefinanceinstitute.com/resources/knowledge /other/hofstedes-cultural-dimensions-theory/

Accessed 11 February, 2021.

[6] “Confucian Analects." The Chinese Classics, translated by James Legge, 2nd ed., Oxford Clarendon Press, 1893.

[7] Hartz, Louis. The Liberal Tradition in America: An Interpretation of American Political Thought since the Revolution. New York: Harcourt, Brace and Company, 1955.

[8] De Tocqueville, Alexis. Democracy in America, Chicago: University of Chicago, 2000.

Lopez, S. “Masks aren' t foolish. Here' s proof.” Los Angeles Times, Section B, 1, 4, 1 May 2020, www.latimes.com/california/story/2020-05-16/.

[9] Kennedy, John F. “Remarks At Amherst College. ” 26 Oct 1963, Amherst, Massachusetts, www.jfklibrary.org/archives/other-resources/johnf-kennedy-speeches/amherst-college-19631026.

[10] Dawsey, Josh, and Yasmeen Abutaleb. “ 'A whole lot of hurt' : Fauci warns of covid-19 surge, offers blunt assessment of Trump' s response." The Washington Post, 10 Oct 2020, www.washingtonpost.com/politics/fauci-covidwinter-forecast/2020/10/31/e3970eb0-1b8b-11ebbb35-2dcfdab0a345_story.html. 
[11] Moreno, J. Edward. “ Trump threatened to fire CDC's chief of respiratory diseases in February: report. " The Hill, 22 Apr 2020, thehill.com/homenews/administration/494187trump-threatened-to-fire-cdcs-chief-of-respiratorydiseases-in

[12] Shear, Michael D, and Maggie Haberman. "Health Dept. Official Says Doubts on Hydroxychloroquine Led to His Ouster." The New York Times, 22 Apr 2020 ,

www.nytimes.com/2020/04/22/us/politics/rickbright-trump-hydroxychloroquinecoronavirus.html.

[13] Barry, Colleen, et al. " Trust in Science and COVID-19” . Johns Hopkins Bloomberg School of Public Health, 17 June 2020, www.jhsph.edu/covid19/articles/trust-in-science-and-covid-19.html.

[14] Kesler, Glenn. Trump says he didn’ t want to spark panic. But he's running on fear. " The Washington

Post,9Sept2020,www.washingtonpost.com/politics/ 2020/09/09/trump-says-he-didnt-want-spark-paniches-running-fear/.

[15] Fuchs, Andreas, et al. "Mask wars: China's exports of medical goods in times of COVID-19." cege Discussion Papers, No. 398, July 2020, University of Göttingen, Center for European, Governance and Economic Development Research (cege), Göttingen.

[16] Popescu, Nicu. "How the Coronavirus Threatens a Geopolitical Europe. " European Council on Foreign Relations, 30 Mar 2020, ecfr.eu/article/commentary_how_the_coronavirus_ threatens_a_geopolitical_europe/.

[17] “Foreign Ministry Spokesperson Hua Chunying' s Regular Press Conference on December 2, 2020. " Ministry of Foreign Affairs of the People' s Republic of China, 2 Dec 2020, www.fmprc.gov.cn/mfa_eng/Xwfw_665399/s2510 _665401/2511_665403/t1837405.shtml. Press Release.

[18] Sutter, Karen M, et al. “COVID-19: China medical supply chains and broader trade issues." Congressional Research Service, 6 Apr 2020, www.everycrsreport.com/files/20200406_R46304_ e2253330d53f6fc8b6394030e8e2eafd2035bfad.pdf

[19] "The face mask global value chain in the COVID19 outbreak: Evidence and policy lessons.” OECD Policy Responses to Coronavirus (COVID-19), May
14, 2020, www.oecd.org/coronavirus/policyresponses/the-face-mask-global-value-chain-in-theCOVID-19-outbreak-evidence-and-policy-lessonsa4df866d/\#back-endnotea0z7.

[20] China National Medical Products Administration. “ Notice. ” 5 Apr 2020 www.nmpa.gov.cn/yaowen/shchjgyw/2020042916 1801471.html.

[21] Wang, Ke. “Dong Zhong Shu De Guan Li Zhe Xue (The management philosophy of Dong Zhongshu). " Journal of Nanyang Institute of Technology, Vol. 2, No. 1, Jan 2020, doi: 10.16827/j.cnki.411404/z.2010.01.027

[22] Glatter, Robert. “Almost 70\% Of Chinese KN95 Masks Don' t Meet Minimum Safety Standards." Forbes, $25 \quad$ Sept 2020, www.forbes.com/sites/robertglatter/2020/09/25/al most-70-of-chinese-kn95-masks-dont-meetminimum-safety-standards/?sh=791e71dc48b9.

[23] “Personal Protective Equipments EUAs." US Food \& Drug Administration. www.fda.gov/medical-devices/coronavirusdisease-2019-covid-19-emergency-useauthorizations-medical-devices/personalprotective-equipment-euas. Accessed 8 Jan 2020.

[24] US Food \& Drug Administration. Letter to Manufacturers of Protective Barrier Enclosures, et al. $20 \quad$ Aug 2020, www.fda.gov/media/141415/download.

[25] “ Coronavirus taught us America is 'overly dependent' on a global supply chain: Peter Navarro. ” Fox Business, 2 Apr 2020, video.foxbusiness.com/v/6146679411001/\#sp=sho w-clips.

[26] Stellinger, Anna, et al. "How trade can fight the pandemic and contribute to global health. " COVID-19 and Trade Policy: Why Turning Inward Won' t Work, edited by Bladwin, Richard, and Simon Evenett, a VoxEU.org eBook, London: CEPR Press. 